\title{
All the queen's horses: statutory authority and HS2
}

Article

Accepted Version

Wilde, M. L. (2017) All the queen's horses: statutory authority and HS2. Legal Studies: The Journal of the Society of Legal Scholars, 37 (4). pp. 765-785. ISSN 1748-121X doi: https://doi.org/10.1111/lest.12173 Available at https://centaur.reading.ac.uk/69485/

It is advisable to refer to the publisher's version if you intend to cite from the work. See Guidance on citing.

To link to this article DOI: http://dx.doi.org/10.1111/lest.12173

Publisher: Wiley-Blackwell

All outputs in CentAUR are protected by Intellectual Property Rights law, including copyright law. Copyright and IPR is retained by the creators or other copyright holders. Terms and conditions for use of this material are defined in the End User Agreement.

\section{www.reading.ac.uk/centaur}

\section{CentAUR}

Central Archive at the University of Reading

Reading's research outputs online 


\section{ALL THE QUEEN'S HORSES: STATUTORY AUTHORITY AND HS2}

\section{ABSTRACT}

This article focuses on the potential impact of the statutory authority defence on HS2 once the line is put into operation. The defence was forged in the heat of the railway revolution. It protects operators from liability in nuisance in respect of certain harms resulting from exercising the statutory powers under which the scheme is authorised. However, the nineteenth century case law established that the defence would only operate in respect of harms which are the inevitable consequence of using those powers. In common with its Victorian forebears, the HS2 project has been authorised by way of an Act of Parliament. Arguably, the HS2 Act is one of the longest, most detailed and highly scrutinised pieces of legislation in history. Nevertheless, it is argued that the scheme may cause uncompensated losses which are not inevitable. In this respect common law actions may yet have an important role to play.

\section{INTRODUCTION}

High Speed 2 phase 1, between London and Birmingham, will be the first intercity mainline to be built in the UK since the close of the Victorian era. ${ }^{1}$ Railway technology has moved on considerably since the heyday of steam and the line will make use of state of the art electric trains. However, the carving of a new mainline railway through the rolling English countryside has resurrected controversies and conflicts which would have been very familiar to the Victorian Railway promoters. Aside from arguments as to whether the project should be undertaken at all, the route and the cost, there are concerns regarding its impact on those who will find themselves living in close proximity to the line.

An unexpected intervention in the highly charged public debate was attributed to Her Majesty the Queen. The line will pass through Stoneleigh Park in Warwickshire where the Queen stables a considerable number of her horses. The Queen is said to have expressed concern at the prospect of her horses being spooked by high speed trains thundering past at speeds of up to $250 \mathrm{mph} .{ }^{2}$ Is it conceivable that once the HS2 line is put into operation Her Majesty, and other persons suffering adverse effects such as noise, could sue the operators in nuisance? Such questions bring us full circle in that the problem of horses being spooked by locomotives gave rise to litigation at the dawn of the railway revolution. In $R v$ Pease $^{3}$ the promoters and enginemen of the Stockton and Darlington

\footnotetext{
${ }^{1}$ In a convenient accident of history the last such mainline to be built, the Great Central, opened in 1899; thus neatly containing the great age of railway building within the nineteenth century. See Christian Wolmar, Fire and Steam: How the Railways Transformed Britain (London: Atlantic Books, 2007) ch 10.

${ }^{2}$ Rosie Kinchen, 'Don't frighten the horses, says Queen' The Sunday Times (London, 19 June 2011) 3.

${ }^{3}$ (1832) 4 B \& Ad 30, 110 ER 366.
} 
Railway, regarded widely as the first railway in the modern sense of the term, ${ }^{4}$ were indicted in public nuisance in respect of the spooking of horses on an adjacent turnpike. The case established the defence of statutory authority which bestows a degree of immunity on the promoters and operators of infrastructure projects in respect of claims in nuisance and Rylands $v$ Fletcher. The concept was developed further by a series of cases on fire damage caused by railway sparks and a number of other cases largely concerning public utilities. The line of authority started by Pease has major implications for current projects.

High Speed 2, in common with other recent rail infrastructure projects such as the Channel Tunnel Rail Link (unofficially referred to as High Speed 1 ) and Crossrail, has been authorised by an Act of Parliament, The High Speed Rail (London - West Midlands) Act (2017) (hereinafter the HS2 (Phase 1) Act) conferring similar immunities in respect of nuisances in certain circumstances. These projects differ from their Victorian counterparts inasmuch as they are the product of central Government planning as opposed to unfettered private speculation. This is reflected in the choice of the hybrid Bill procedure rather than private Bill procedure. Nevertheless, the statutory authority defence, as developed and refined in the nineteenth century, is still highly relevant. However, there are major uncertainties in terms of how it would be interpreted in the context of twenty first century rail projects.

Although HS2 has strong links with its Victorian railway heritage, there are major differences in the political and legal landscape which now prevails. The HS2 Bill and its associated documents was one of the weightiest pieces of legislation ever laid before Parliament. This is largely due to the 50,000 environmental assessment which had to be conducted under EU law. It had to navigate a lengthy and cumbersome legislative procedure which included the taking of evidence from thousands of petitioners. Moreover, developments in civil society, the media, access to information and information technology means that it was subjected to an unprecedented degree of public scrutiny. The increased availability of judicial review enabled objections to be channelled into legal challenges which threatened to derail the project. Finally, the Government felt compelled to establish a discretionary compensation system which goes far beyond the statutory minimum. In the light of such intense scrutiny it is natural to ask whether there can possibly be any room left for the common law to operate.

When railway technology was in its infancy it is a fair assumption that Parliament failed to anticipate many of the adverse consequences which followed. Given the detailed nature of the planning and

\footnotetext{
${ }^{4}$ See Maurice W. Kirby, The Origins of Railway Enterprise: The Stockton and Darlington Railway $1821-1863$ (Cambridge: CUP, 1993).
} 
legislative procedures pertaining to HS2 it is far less likely that harms will simply be unforeseen, thereby necessitating a corrective role for the common law at a later stage. Where harms are foreseen but deemed unavoidable it is likely that some form of compensation will be available under existing statutes or the HS2 discretionary compensation scheme. Nevertheless, it is argued that it will not be possible to ascertain the full impact of the line until it is put into operation. A decision not to build a short section of noise fence barrier at a specific location may have serious implications for a particular neighbour. In addition, a person may find that he is just beyond the reach of the outer limits of the compensation scheme, but must nevertheless endure nuisances which are not sensibly different from those affecting his neighbours on the right side of the cut-off point. The role of the common law is to remediate very specific and individual harms which may not have been catered for by the broad sweep of the planning system. This does not necessarily mean that there has been 'regulatory failure' necessitating corrective action by the common law. Rather, it is possible to envisage the common law as 'fine-tuning' the planning process by addressing such localised harms.

However, there is a crucial doctrinal issue at the heart of statutory authority the interpretation of which is critical to the ability of the common law to fulfil this role effectively. The statutory authority defence only operates in respect of harms which are the inevitable result of the use of the statutory powers in question. In order for the common law to operate effectively, the courts would need to approach evidence that harm was the inevitable consequence of operating high speed trains with a degree of circumspection. However, it is also argued that any such analysis must take on board issues of technical feasibility and cost.

As regards the structure of the article the scene is set by outlining the nature and origins of statutory authority and the key doctrinal developments. This traces the emergence of the inevitability of harm criterion by way of a number of complex case law developments in the field of railways and other infrastructure projects. Particular attention is paid to the railway sparks cases in which the courts arguably failed to adopt a sufficiently critical approach regarding claims that such damage was an inevitable consequence of using powers to operate steam locomotives. This is followed by an overview of the hybrid Bill procedure and the passage of the HS2 Bill though Parliament focusing on the petitioning process and Environmental Assessment. It is argued that, notwithstanding this level of scrutiny, it is still highly likely that not all harms will have been anticipated and designed out of the scheme or at least mitigated at the planning stage. Moreover, there can be no assumption that any harms which do occur, notwithstanding the rigorous nature of the legislative procedures, can be regarded as inevitable. The article then considers the possibility that the defendant could simply sidestep arguments about statutory authority and whether the harm was inevitable by invoking the 
locality doctrine. This would entail showing that there was no prima facie cause of action in nuisance in the first place on the grounds that the railway had changed the character of the neighbourhood. Here it is argued that recent case law developments signal a move away from the assertion that planning decisions can bring about instant and dramatic changes in the locality. Finally, the adequacy of compensation offered by existing statutes and the discretionary HS2 scheme is examined. Clearly, if a claimant was already automatically entitled to adequate compensation under these schemes recourse to the common law would not be necessary. However, it is concluded that there are limitations associated with the compensation schemes and that they do not offer a complete alternative to the common law.

\section{THE ORIGINS AND DEVELOPMENT OF STATUTORY AUTHORITY}

\section{The constitutional backdrop to statutory authority}

The defence of statutory authority emerged in the nineteenth century, largely as a result of the Railway Revolution where private Acts of Parliament were used to authorize the many hundreds of schemes. ${ }^{5}$ The Railway Revolution was an aspect of the Industrial Revolution which brought about a recalibration of the relationship between common law and legislation made by Parliament. In many respects statutory authority is a product of this recalibration. Although the sovereignty of Parliament was deeply entrenched by the onset of the nineteenth century, Parliament was not regarded as the primary source of law. Lord Melbourne famously stated that 'the duty of a government is not to pass legislation but to rule. ${ }^{6}$ As Lord John Russell noted in 1841, the elder Pitt did not carry a single legislative measure through Parliament. ${ }^{7}$ Industrialization rendered this situation untenable in that the rate of technological progress and the magnitude and complexity of the resulting issues demanded instant and sophisticated legal solutions. The common law could not offer these solutions in that it was reactive rather than proactive and hidebound by precedent.

However, as Pollock explained, the courts were rightly sceptical about the competence of Parliament as a law maker and normally construed statutes as operating without prejudice to existing common

\footnotetext{
${ }^{5}$ For the leading historical account of the role played by law in the Victorian Railway Revolution see R.W. Kostal, Law and English Railway Capitalism: 1825 - 1872 (Oxford: Clarendon Press, 1994).

${ }^{6}$ Cited in O MacDonagh, Early Victorian Government 1830 - 1870 (London: Weidenfeld and Nicolson , 1977) p 5.

${ }^{7}$ Cited in A Walkland, The Legislative Process in Great Britain (London: George, Allen \& Unwin, 1968) p 12.
} 
law rights. ${ }^{8}$ The bureaucracy necessary to formulate effective legislation evolved in tandem with industrialisation with much trial and error along the way. ${ }^{9}$ Nevertheless, the courts were eventually persuaded that, in order to give effect to the will of Parliament, the common law needed to be construed in a way which facilitated the abrogation of existing rights. This is strongly reflected in the development of statutory authority; as Lindley put it:

...the courts were understandably reluctant to flout the will of Parliament by enjoining these legislatively authorised activities, even where damage to individuals would result.

Paradoxically, democracy was preserved by the sacrifice of individual rights. The victims of progress had to bear their losses with such stoicism as they could muster. ${ }^{10}$

This links statutory authority with Parliamentary sovereignty in that the defence can be viewed as a means of giving effect to the will of Parliament. However, given that both concepts are constructs of the common law, ${ }^{11}$ the courts have a vital role to play in terms of defining the scope of any powers conferred on an entity by Parliament. Thus, statutory authority has given rise to debates about the need for clear and express words in the statute purporting to limit common law rights, the avoidability or otherwise of the harm and the requirement for alternative compensation mechanisms. As will be seen, all these elements are relevant to the HS2 debate. Whether the courts have always been effective in terms of keeping statutory powers within acceptable bounds is open to question and Linden observed that on occasion 'they have enlarged the scope of the operation of legislation beyond the fondest expectations of the draftsmen. ${ }^{12}$ Indeed, as will be seen below, the railway companies laid waste countless acres of farmland through fire damage without the need to pay compensation and one must question whether this could have been within Parliament's contemplation.

\footnotetext{
8 '...the King's judges always looked on legislative interference with some jealously too often warranted by the unworkmanlike manner in which Parliament has laid hands on the Common Law': Sir Frederick Pollock, The Expansion of the Common Law (London: Stevens and Sons, 1904) p 121.

${ }^{9}$ PS Atiyah, The Rise and Fall of Freedom of Contract (Oxford: Clarendon, 1979) ch 9 - 'the Role of Government, 1770 - 1870'.

${ }^{10}$ See AM Linden, 'Strict Liability, Nuisance and Legislative Authorisation' (1966) 4 Osgoode Hall L 196 at 198.

${ }^{11}$ See Lord Steyn in R (on the Application of Jackson) v Attorney General [2005] UKHL 56, [2006] 1AC 262 at [102]: '...supremacy of Parliament is still the general position of our constitution. It is a construct of the common law. The judges created this principle...'

12 Linden, above $\mathrm{n} 10$, at 196.
} 


\section{The early development of statutory authority}

The development of statutory authority is largely attributable to the rapid expansion of the railways in the nineteenth century. In $R v$ Pease ${ }^{13}$ the enginemen and directors of the Stockton and Darlington Railway were indicted in public nuisance in respect of the spooking of horses on the Yarm turnpike by the operation of steam locomotives. ${ }^{14}$ The Court of Kings Bench accepted an argument to the effect that, where Parliament has sanctioned a particular activity, there can be no liability in respect of certain harms arising from the activity. It is important to note that the private Act under which the line was authorised ${ }^{15}$ contained a specific provision sanctioning the use of steam locomotion. ${ }^{16}$ This had been added following a meeting between the famed George Stephenson and the lead promoter, Edward Pease, in which the former had persuaded the latter to use steam locomotives. ${ }^{17}$ Hitherto motive power on the early waggonways had normally been provided by horses or stationary winding engines. The provision proved pivotal in the outcome of the case in that it put beyond doubt that Parliament had expressly authorised the use of the technology, notwithstanding its consequences. A similar power was later enshrined in section 86 of the Railway Clauses (Consolidation) Act $1845^{18}$ which rendered it 'lawful for the Company to use and employ locomotive Engines or other moving Power...'

Section 86 of the 1845 Act had a major effect on the outcome of the railway sparks cases ${ }^{19}$ arising from the extensive fire damage caused by passing steam locomotives. In short, it largely thwarted attempts to impose strict liability on the railway companies in respect of this type of harm. ${ }^{20}$ In the absence of fault it was assumed that the railway company had acted within the scope of its statutory powers and would thereby be protected from liability. ${ }^{21}$ The importance of section 86 was

\footnotetext{
13 Pease, above $\mathrm{n} 3$.

${ }^{14}$ For a historical analysis of the case see Mark Wilde and Charlotte Smith, 'R v Pease (1832)' in Charles Mitchell and Paul Mitchell (eds), Landmark Cases in the Law of Tort (Oxford: Hart, 2010).

151823 (4 Geo 4 c 33).

${ }^{16} \mathrm{Ibid}$, section 8 .

${ }^{17}$ WW Tomlinson, The North Eastern Railway: Its Rise and Development (London: Longmans, Green \& Co, 1915) pp 72-73 and 84-85.

${ }^{18}$ The legislation was designed to standardise certain provisions in the myriad private Bills under which the railways were authorised. See Frederick Clifford, A History of Private Bills Legislation: volume 1 of 2 (1887, Abingdon: Routledge, 2013) pp $102-103$.

${ }^{19}$ The cases are well-known in tort scholarship due to their use as examples in the economic analysis of tort where debate focuses on the efficiency of certain rules for determining whether the loss should fall on the farmer, whose crops were destroyed, or the railway company. See AC Pigou, The Economics of Welfare (London: Macmillan, 4th edn, 1932) at [II.II.5]; RH Coase, 'The Problem of Social Cost' (1960) $3 \mathrm{~J}$ Law Econ 1 at 28-34.

${ }^{20}$ For a succinct overview of the key case law developments see Jonathan Morgan, 'Technological Change and the Development of Liability for Fault in England and Wales' in Miquel Martin-Casals (ed), The Development of Liability in Relation to Technological Change (Vol 4) (Cambridge: CUP, 2010) pp 40-51.

${ }^{21}$ See Vaughan v Taff Vale Rly Co (1860) 5 Hurl \& N 679, 157 ER 1351.
} 
underscored in Jones $v$ Festiniog Rly $\mathrm{CO}^{22}$ in which, following the adoption of steam locomotion on a railway which had hitherto been operated by horses and stationary winding engines, steps had not been taken to amend the original legislation. This enabled Blackburn J, who had recently cemented his place in legal history with his rule of strict liability in the eponymous case of Rylands $v$ Fletcher, ${ }^{23}$ to apply the rule to the case at hand. In the vast majority of cases, however, the railway companies enjoyed the requisite statutory powers. Claims continued to be brought as straightforward actions on the case for negligence and statutory authority dispelled any notion that a stricter form of liability could be applied. ${ }^{24}$

As regards other types of harm arising from the railways, in Hammersmith and City Rly Co v Brand ${ }^{25}$ damages in private nuisance were sought in respect of vibration. The House of Lords held that, provided it could be shown that 'locomotives cannot possibly be used' ${ }^{26}$ without causing such loss, section 86 of the 1845 Act would negate liability. This touches on one of the most important doctrinal aspects of statutory authority, namely, the inevitability of the harm. The emergence of this criterion is complex and requires a degree of explanation.

\section{The 'inevitability of harm' criterion}

As noted above, the statutory authority defence prevented strict liability from operating in the vast majority of the railway sparks cases. For the most part, such claims proceeded as actions on the case for negligence and attention focused on whether reasonable steps had been taken to reduce the risk of fire. For example, there was much debate about the necessity of fitting spark arrestors to locomotives. ${ }^{27}$ However, such devices were unpopular with the railway companies in that they tended to impair the performance of locomotives. They eventually persuaded the courts that the fitting of spark arrestors should not be regarded as a prerequisite for discharging the duty of care in that the benefits of the devices had to be balanced against the costs. ${ }^{28}$ Thus, issues of technical feasibility and cost were filtered into the assessment of the appropriate standard of care. ${ }^{29}$

\footnotetext{
22 (1867-68) LR 3 QB 733.

${ }^{23}$ Fletcher $v$ Rylands (1865-66) LR 1 Ex 265.

24 In the early twentieth century some limited relief was offered to farmers suffering crop damage by way of the Railway Fires Act 1905.

25 (1869-70) LR 4 HL 171.

${ }^{26} \mathrm{Ibid}$, at 202, per Lord Chelmsford.

${ }^{27}$ See, for example, Piggot v Eastern Counties Railway Co (1846) 3 CB 229, 136 ER 9.

${ }^{28}$ See Port-Glasgow and Newark Sailcloth Company and Others v The Caledonian Railway Company (1893) 20 R (Ct of Sess) (HL) 35.

${ }^{29} \mathrm{Ibid}$. In this respect the case imported the concept of Best Practicable Means (BPM) from administrative law. An early example of the concept appears in section 104 of the Town Improvement Clauses Act 1847 establishing an early form of statutory nuisance.
} 
Negligence in the wider sense of the term, as an adjective for fault as opposed to a cause of action in its own right, operated somewhat differently in nuisance cases. In the railway sparks cases statutory authority simply prevented strict liability from displacing negligence. Nuisance actions, on the other hand, started from a position of strict liability in that this was the essence of the tort. Thus, it was necessary to proceed to an analysis of fault in order to determine whether the defence could be maintained. In Shelfer $v$ City of London Electric Lighting $\mathrm{CO}^{30}$ the Court of Appeal held, obiter, that the onus lay on the defendant to show that it was 'impossible' to avoid the harm. ${ }^{31}$ This was clearly a very much higher standard than that typically set by the duty of care in negligence.

Shelfer was followed by the House of Lords in Manchester Corporation v Farnworth ${ }^{32}$ in which Viscount Dunedin held that the onus would be on the defendant to show that the harm was 'inevitable. ${ }^{33}$ However, the judgment somewhat conflated the railway sparks cases with the nuisance cases with the result that the inevitability criterion was tempered by issues of technical feasibility and cost. ${ }^{34}$ This resulted in a formulation of inevitability which was somewhat less onerous than the need to show that it was impossible to avoid the harm. However, in the other major House of Lords decision on statutory authority and infrastructure projects, Allen v Gulf Oil Refining Ltd, ${ }^{35}$ Lord Edmund-Davis adopted a much stricter approach. Thus, where a prima facie actionable nuisance has been established: 'it would be for the defendant to establish that any proved nuisance was wholly unavoidable, and this quite regardless of the expense which might necessarily be involved in-its avoidance ' [emphasis added]. ${ }^{36}$

Despite the mistaken conflation of the railway sparks and nuisance cases, Lord Dunedin's formulation in Farnworth is to be preferred in that it accords more closely with modern technical environmental standards such as Best Available Techniques (BAT). ${ }^{37} \mathrm{~A}$ common law test which took no account of expense would be impractical and could increase the costs of schemes to the extent that they become unworkable. This would be at odds with the very purpose of statutory authority which is to ensure that projects deemed to be in the public interest can proceed notwithstanding the damage caused to some individual interests.

\footnotetext{
${ }^{30}$ [1895] 1 Ch 287.

31 Ibid, at 313, per Lindley LJ.

32 [1930] AC $171(\mathrm{HL})$.

$33 \mathrm{lbid}$, at 183.

34 Ibid.

35 [1981] AC 1001 (HL).

${ }^{36} \mathrm{Ibid}$, at $1015 \mathrm{E}$.

37 The definition of BAT in the Industrial Emissions Directive makes it clear that issues of cost are encompassed by the 'availability' component of the standard. See European Council and Parliament Directive (EU) 2010/75 on industrial emissions (integrated pollution prevention and control) [2010] OJ L334/17, art 3(10)(b).
} 


\section{Statutory authority and the railway revolution}

The statutory authority defence is deeply rooted in the history of the railways and this heritage is acknowledged in both the leading 20th century authorities on the defence. As Lord Denning said with the regard to the seminal Pease ${ }^{38}$ case, 'That decision was highly beneficial. It opened the way to the Railway Age. G. M. Trevelyan says that "the railways were England's gift to the world" (Social History, p. 531). ${ }^{39}$ Indeed, it is difficult to see how the railways could have developed without the development of statutory authority. However, Lord Denning was also of the opinion that the defence may have gone too far in terms of authorizing substantial harms, without making provision for compensation, and cited the Vaughan $v$ Taff Vale Railway ${ }^{40}$ case in this respect. In this case eight acres of woodland were destroyed without compensation; Lord Denning described this outcome as 'exceedingly hard on the landowner. ${ }^{41}$ This raises the issue of the extent to which the inevitability of harm criterion can be used to temper the worst effects of major infrastructure projects. This will provide the focus of the following analysis on the potential impact of statutory authority on HS2.

\section{HS2 AND STATUTORY AUTHORITY}

\section{Hybrid Bills}

Whereas railways in the nineteenth century were largely authorised by way of the private Bill procedure ${ }^{42} \mathrm{HS} 2$, in common with other recent major rail projects, ${ }^{43}$ has been authorised under the hybrid Bill procedure. ${ }^{44} \mathrm{~A}$ hybrid Bill combines elements of private and public Bill procedure and reflects the greater degree of central planning and government involvement in modern transport projects. However, the incorporation of private Bill elements, principally the select committee and petitioning stages, reflects the impact of such projects on specific interests. The HS2 Bill was introduced in the House of Commons on 25 November $2013^{45}$ and received the Royal Assent on 23 February 2017 having undergone a gruelling legislative journey including select committees and petitioning in both Houses of Parliament. It should be noted that major infrastructure projects, including new railways over a certain length, are subject to planning procedures introduced by the Planning Act 2008 and it was necessary to specifically exempt the project from the jurisdiction of the

\footnotetext{
38 n 3 above.

${ }^{39}$ Allen v Gulf Oil Refining Ltd [1980] QB 156 (CA) at $165 C$.

${ }^{40}$ Above $\mathrm{n} 21$.

${ }^{41}$ Above n39, at $165 \mathrm{E}$.

${ }^{42}$ See Kostal, above $n 5$.

${ }^{43}$ See the Channel Tunnel Act 1987, Channel Tunnel Rail Link Act 1996 and the Crossrail Act 2008.

${ }^{44}$ For a full account of hybrid Bill procedure see Malcom Jack (ed), Erskine May Parliamentary Practice (London: Lexisnexis/Butterworths, 24th edn, 2011) pp 652-659.

${ }^{45}$ HC Deb vol 571 col 4725 November 2013.
} 
HS2 (Phase 1) Act. ${ }^{46}$ The reasons for utilising the hybrid Bill procedure as opposed to the 2008 Act do not appear to be in the public domain. However, White surmises that it would be problematic using the 2008 Act to authorise long linear projects, such as new intercity railways, due to the need to consult all local authorities along the route. ${ }^{47}$

\section{Statutory authority and HS2}

Schedule 27 of the HS2 (Phase 1) Act specifically incorporates section 86 of the Railway Clauses (Consolidation) Act 1845 which clearly establishes a defence of statutory authority. ${ }^{48}$ As the foregoing historical analysis demonstrates, this provision played a crucial role in limiting the liability of the railway companies for harms such as railway fires, noise and vibration. In this respect there is a clear strand of law which links HS2 with its Nineteenth Century railway heritage. Moreover, the legislation puts no additional gloss on the concept and one can assume that the statutory authority defence will come equipped with its common law baggage. Thus, there can be no expectation that the Act will afford the operators blanket immunity in respect of harms arising from the operation of the line. In particular, the statutory authority defence will not offer the operator any protection where the harm cannot be regarded as the inevitable consequence of exercising the statutory powers.

Nevertheless, it must be acknowledged that it may prove difficult to argue that a nuisance caused by HS2 was not inevitable. Unlike the power station in Farnworth ${ }^{49}$ and the oil refinery in Allen, ${ }^{50}$ HS2 has been subject to a forensic and immensely detailed consideration of its environmental effects including noise and vibration. ${ }^{51}$ Moreover, in the early nineteenth century railway technology was in its infancy and it can be surmised that the legislators did not fully appreciate the magnitude of the fire risk and so forth. High speed rail technology, on the other hand, is now over fifty years old ${ }^{52}$ and much of the controversy surrounding HS2 seems to overlook the existence of HS1. There is no great

\footnotetext{
${ }^{46}$ Section 24.

${ }^{47}$ Matthew White, 'Attaining the age of consents: five years of the Planning Act 2008' (2013) JPL OP100 at OP142. The duty to consult is set out in section 42 of the 2008 Act.

${ }^{48}$ See also section 122 of the Railways Act 1993 which sets out a statutory authority defence in respect of the rail network as a whole, of which HS2 will eventually form part.

${ }^{49}$ Farnworth (HL), above $\mathrm{n} 32$.

${ }^{50}$ Allen (HL), above $\mathrm{n} 35$.

${ }^{51}$ See Department for Transport and High Speed Two (HS2) Ltd, 'HS2 Phase One environmental statement volume 5: sound, noise and vibration' (25 November 2013) available at https://www.gov.uk/government/publications/hs2-phase-one-environmental-statement-volume-5-soundnoise-and-vibration (accessed 2 February 2017).

${ }^{52}$ The technology was of course pioneered with the Japanese Bullet trains (Shinkansen) the first of which started operating in 1964. See Terry Gourvish, The High Speed Rail Revolution: History and Prospects (2010) (research paper prepared for HS2 Ltd) available at http://www.railwaysarchive.co.uk/documents/HS2_TheHighSpeedRailRevolutionHistoryAndProspects2010.pd $f$ (accessed 2 February 2017).
} 
mystery regarding the impact of high speed rail on the environment and one has only to make a short field trip to Kent to witness its effects. ${ }^{53}$

Accordingly, it is far less likely that harms will simply have been unforeseen or overlooked, as occurred in Farnworth ${ }^{54}$ and Allen, ${ }^{55}$ with the result that it is improbable that the common law will be called upon to correct 'regulatory failure' ${ }^{56}$ Nevertheless, notwithstanding the rigors of the legislative procedures which shall be reviewed below, it is folly to assume that all potential harms at specific locations will have been identified and dealt with at the planning stage.

\section{Hybrid Bill procedure and the consideration of environmental effects}

There are major procedural differences in enacting railway Bills in the twenty-first as opposed to the nineteenth century, not least of which is the need to produce an environmental statement in accordance with EU law on environmental assessment. ${ }^{57}$ The environmental statement accompanying the HS2 Bill for phase 1 of the project ran to some 50,000 pages. ${ }^{58}$ In 2014 a number of objectors sought judicial review of the scheme on the grounds that there had been a failure to comply with various aspects of environmental assessment. ${ }^{59}$ One of the main arguments was that the original policy commitment to build $\mathrm{HS}^{60}$ should have triggered a strategic environmental assessment (SEA) before legislation was introduced. ${ }^{61}$ This was rejected on the grounds that an SEA is only triggered where a strategic planning decision binds those bodies charged with making

\footnotetext{
${ }^{53}$ See Mark Odell, 'How the first high-speed rail spat ended peacefully' Financial Times (London, 13 January 2012).

${ }^{54}$ Ben Pontin, Nuisance Law and Environmental Protection: A study of nuisance injunctions in practice (Witney: Lawtext, 2013) ch 4.

${ }^{55}$ See Mark Wilde, 'Nuisance law in industrial Wales - local and national conflicts (part two): oil refining, the common law and regulation' in Patrick Bishop and Mark Stallworthy (eds), Environmental Law and Policy in Wales: Responding to Local and Global Challenges (Cardiff: University of Wales Press, 2013).

${ }^{56}$ See Mark Stallworthy, 'Environmental Liability and the Impact of Statutory Authority' (2003) JEL 15 (1) 3 at 8.

${ }^{57}$ European Parliament and Council Directive 2011/92/EU of 13 December 2011 on the assessment of the effects of certain public and private projects on the environment [2011] OJ L26/1 (codifying the original EIA Directive 85/337/EEC and its subsequent amendments). Note that the consolidating Directive 2011/92/EU has now itself been amended by way of Council Directive 2014/52/EU [2014] OJ L124/1. Strictly speaking the Directive exempts projects authorised by way of legislation from EIA (see Article 1(4)) but this is contingent upon the existence of equivalent legislative procedures which are capable of meeting the aims of the Directive. To this end House of Commons Standing Order 27A requires the preparation of an environmental statement and Standing Order 224A affords consultation rights to the public.

58 The HS2 phase 1 environmental statement can be accessed at

https://www.gov.uk/government/collections/hs2-phase-one-environmental-statement-documents (accessed 1 February 2017).

${ }^{59} R$ (on the application of Buckinghamshire County Council and others) v Secretary of State for Transport [2014] UKSC 3, [2014] 1 WLR 324.

${ }^{60}$ See Department for Transport, High Speed Rail: Investing in Britain's Future - Decisions and Next Steps Cm 8247 (2012).

${ }^{61}$ Pursuant to European Parliament and Council Directive 2001/42/EC on the assessment of the effects of certain plans and programmes on the environment [2001] OJ L197/30 (SEA Directive).
} 
planning decisions within the policy framework. This could not be the case here because Parliament is sovereign and cannot be bound by such a policy commitment. ${ }^{62}$ Further arguments pertaining to the compatibility of Parliamentary procedures with environmental impact assessment during the course of the legislative process were also rejected. The political nature of such planning decisions and the fact that the Bill would be subject to a three line whip did not render the whole process inherently unsound. ${ }^{63}$ Having survived the challenge the Bill proceeded to the Select Committee stage.

The main function of the Select Committee in the hybrid Bill procedure is to hear petitions brought by those adversely affected by a scheme and to propose amendments and refinements such as additional mitigation measures.$^{64}$ It is not allowed to consider the desirability of a project as a whole as this decision has already been taken by Parliament at second reading. The House of Commons HS2 Select Committee sat for 160 days and heard evidence from some 1,600 petitioners, some of whom included equestrians expressing similar concerns to those attributed to Her Majesty the Queen. ${ }^{65}$ An interesting aspect of the proceedings was that the promoter was free to strike deals with petitioners in the corridor outside the committee room. ${ }^{66} \mathrm{In}$ fact this process was actively encouraged by the Committee ${ }^{67}$ and led to a number of petitions being withdrawn. ${ }^{68}$ The process was repeated in the House of Lords where 821 petitions were received although not all of those progressed to a full hearing. ${ }^{69}$

It is clear that the environmental effects of HS2 phase 1, including noise levels and vibration, have been subject to a much greater degree of Parliamentary scrutiny than was the case in respect of

\footnotetext{
62 Above n 59, Lord Carnwath at [38].

63 Ibid, Lord Reed at [103].

64 The Committee published its final report on 22 February 2016 and made a number of directions and recommendations including extending the tunnel under the Chilterns and improving noise mitigation at Wendover. See Select Committee on the High Speed Rail (London - West Midlands Bill), High Speed Rail (London - West Midlands) Bill (second special report) (HC 2015-16).

65 One petitioner, for example, claimed that 'The sudden and unexpected noise spikes and flash movement of $200+$ mph trains will be directly responsible for the inherently unpredictable behaviour of equines and other farm animals': High Speed Rail (London-West Midlands) Bill Petition 0575 (Sheila Ann Cooper, 2014) at[10]: http://www.publications.parliament.uk/pa/cmhs2/petitions/petcontents.htm (accessed 17 December 2015). ${ }^{66}$ For an interesting first-hand account of the manner in which such negotiations were conducted see Adam King, 'Inside story of how eleventh hour HS2 deal for Bucks was struck in the corridors of Westminster' Buckingham and Winslow Advertiser (Buckingham, 27 January 2016) https://media.info/newspapers/titles/buckingham-and-winslow-advertiser (accessed 1 February 2017). ${ }^{67} \mathrm{Mr}$ Robert Syms MP, 'High Speed Rail Select Committee: Statement by the Chair' (11 February 2015) http://www.parliament.uk/business/committees/committees-a-z/commons-select/high-speed-rail-londonwest-midlands-bill-select-committee-commons/news/chairs-statement-10-feb/ (accessed 17 December 2015). ${ }^{68}$ According to Ben Ruse, HS2 Ltd Director of Communications: see Ben Ruse, 'HS2 Matters: The focus has shifted to why the country needs HS2' Rail 765 (7-20 January 2015) 18.

${ }^{69}$ Select Committee on the High Speed Rail (London - West Midlands Bill), High Speed Rail (London - West Midlands) Bill (special report of session) (HC 2016-17).
} 
projects from an earlier age. The process will be repeated in the run up to the Bills needed to authorise HS2 phases $2 \mathrm{a}$ and $2 \mathrm{~b}$. Matters have advanced considerably since the enactment of the Channel Tunnel Bill which was perceived, in some quarters, as a means of steamrollering through a government policy without regard to concerns raised by the residents of Kent. ${ }^{70}$ Nevertheless, as we have seen, it is unrealistic to assume that all harms will have been anticipated with a view to designing them out of the scheme or making provision for compensation. Not all affected parties will have had the wherewithal to submit a petition and, even where a petition has been submitted, there is no guarantee that the petitioner will achieve satisfaction. Finally, it must be noted that environmental assessment is essentially a procedural requirement and, although the decision maker must show that he has given due consideration to the findings of the environmental statement, he is not bound to accede to all of its findings. ${ }^{71}$ This is one potential weakness in environmental assessment as it relates to hybrid Bill procedure. In a conventional planning application elements of the environmental statement can be reflected in planning conditions. ${ }^{72}$ As regards hybrid Bills, at no point in the legislative procedure does the Environmental Statement become annexed to the Bill. ${ }^{73}$ The deposited plans, which were annexed to the Bill at the outset, are confined to issues of route alignment and the positioning of key items of infrastructure such as bridges and tunnels. ${ }^{74}$ To a large extent the politicians voting on the Bill must take it on trust that the environmental mitigation will be carried out. ${ }^{75}$ To this end the relevant minister must make a statement before third reading which outlines the Government's reasons for supporting the scheme and summarises the main mitigation

\footnotetext{
${ }^{70}$ See Eve Darian-Smith, Bridging Divides: the Channel Tunnel and English Legal Identity in the New Europe (London: University of California Press, 1999) pp 121-122.

${ }^{71}$ Note the wording of Article 8 of the EIA Directive, $\mathrm{n} 57$ above, which states that the information produced by the EIA 'shall be taken into consideration in the development consent procedure.'

72 Department for communities and local government, 'Environmental Impact Assessment' (Planning Practice Guidance, 6 March 2014), [051] http://planningguidance.communities.gov.uk/blog/guidance/environmentalimpact-assessment/considering-and-determining-planning-applications-that-have-been-subject-to-anenvironmental-impact-assessment/ (accessed 17 December 2015).

${ }^{73}$ One can surmise that the separation of EIA from the Bill itself results from a desire to prevent the Bill from becoming unwieldy and to allow for some flexibility in the execution of the works. There is long standing precedent for such an approach; for example, the Gulf Oil Refining Act 1965, which was at issue in the Allen case (above $n$ Error! Bookmark not defined.) was largely confined to the powers needed to acquire land and so forth. Much of the fine detail relating to design and configuration of the plant was left to standard planning procedures under the Town and Country Planning Acts. Although, as the litigation demonstrates, environmental protection did not feature heavily in the planning decisions made under that part of the process.

${ }^{74}$ The 'deposited plans' are contained in separate documents but are specifically incorporated in the HS2 Bill by way of section 57 thereof. The plans and all other Bill documents can be accessed at the following Government website: https://www.gov.uk/government/collections/high-speed-rail-london-west-midlands-bill (accessed 17 December 2015). Hard copies of all documents have also deposited in libraries at locations affected by both phase 1 and 2 of the HS2 project.

${ }^{75}$ This might explain why some MPs proposed a new clause 8 establishing the Office of the HS2 Adjudicator to Protect the Environment and Communities. The body would have had statutory powers to enforce certain environmental duties. The amendment was rejected during the Commons Report Stage debate: . see HC Deb 23 March 2016, vol 607, cols 1659-60.
} 
strategies ${ }^{76}$ It must be acknowledged that the political fallout of a wholesale abandonment of the environmental statement during construction would be colossal and would jeopardize the prospects of further HS2 Bills on phases $2 \mathrm{a}$ and $2 \mathrm{~b}$ of the scheme to Manchester and Leeds. It would constitute a gross abuse of trust on the part of the promoters in that they would have placed the Government in the position of having misled Parliament into supporting the Bill at third reading; there is no doubt that HS2 executives would be roasted before Parliamentary committees. Moreover, future Bills would be open to new challenges by way of judicial review on the grounds that domestic legislative procedures had proved themselves to be too weak to ensure effective environmental impact assessment. ${ }^{77}$

\section{The role of nuisance and HS2}

Nevertheless, whilst such a systematic disregarding of the environmental statement is unimaginable, it is conceivable that there could be some limited departures from the statements at specific locations. If such a deviation from the statement exposed an individual to a nuisance he would have a strong case that the harm was not inevitable in that it had clearly been contemplated by the planners. In any event, even in the absence of any specific departure from the environmental statement, we have already seen that a particular harm may simply have been unforeseen or left uncompensated.

This could leave some room for the common law of nuisance to operate as a means of closing any gaps left by the environmental impact and petitioning processes. In order to illustrate this it is possible to draw upon an example from a much smaller rail project authorized under different planning procedures. The proprietors of a livery yard and riding school adjacent to a section of line being upgraded and reopened to passenger services as part of the Chiltern Railways Evergreen 3 project objected, pursuant to procedures under the Transport and Works Act 1992, ${ }^{78}$ on the grounds that the horses were only accustomed to much slower and more infrequent train movements. They feared that fasting moving passenger trains would startle horses and interfere with riding lessons, notwithstanding the fact that these are conventional trains which will only operate at a fraction of

\footnotetext{
${ }^{76}$ House of Commons Standing Order 224A(9). As regards HS2 this statement was made to the House by Patrick McLoughlin, Secretary of State for Transport, on 23 March 2016 in moving third reading of the Bill: HC Deb 23 March 2016, vol 607, cols 1666-68.

77 It remains to see what elements of environmental assessment will remain after BREXIT but the second phases of HS2 are proceeding on the basis that it will be a requirement for the for the foreseeable future. See AJ Bond et al, 'Environmental impact assessment in the UK after leaving the European Union' (2016) 34(3) IAPA 271.

78 The Act empowers the Minister to authorize projects by way of Ministerial Order; a public inquiry can be instigated under section 11 at which objections can be aired.
} 
the speed of trains on $\mathrm{HS} 2$, and sought the erection of a noise barrier along the boundary. ${ }^{79}$ In the event that no requirement for noise mitigation is made, this is precisely the type of localized harm in which the common law could have a role to play in terms of focusing attention on whether such harm is inevitable and a reasonable price to pay for the wider benefits of the scheme. As noted above, in making this determination a formulation of the inevitability criterion should be adopted which incorporates elements of technical feasibility and cost. ${ }^{80}$ The ability of objectors to insist upon 'gold-plated' solutions, such as more tunnelling to hide the line and entirely stifle noise nuisances, would cause costs to spiral out of control and undermine the viability of the scheme. ${ }^{81}$

Thus, although the common law may not be needed to correct 'regulatory failure', it may nevertheless have a role to play in terms of 'fine tune' the planning process. ${ }^{82}$ However, even where a claimant can establish that harm was not inevitable, there remains an additional doctrinal aspect of nuisance which could nevertheless defeat the action. In some circumstances otherwise valid claims can be neutralized by a change in the character of the neighbourhood.

\section{STATUTORY AUTHORITY AND THE CHARACTER OF THE NEIGHBOURHOOD}

The statutory authority defence proceeds on the basis that all the essential components of nuisance are established and that there is, therefore, a prima facie cause of action. In terms of establishing the prima facie claim, those claiming in respect of harm which does not amount to physical damage

\footnotetext{
${ }^{79}$ See documents pertaining to the Chiltern Railways (Bicester to Oxford Improvements) Order Re-Opened Public Inquiry: Document OBJ238/9 - Representation by John Offord on behalf of Mr and Mrs Offord and Mr and Mrs Bradshaw http://www.chiltern-evergreen3.co.uk/index.php/2012-objector-documents (accessed 17 December 2015).

$80 \mathrm{lbid}$. The objectors argued that the cost of the barrier ( $£ 50,000$ to $£ 100,000)$ was modest given that a spooked horse in a riding lesson could cause a serious accident and that the promoter's costings stipulated that an investment of $£ 1.6 \mathrm{~m}$ should be made per life saved.

${ }^{81}$ Objectors to HS2 have called for ever more tunnelling and a lengthy tunnel is already proposed for the Chilterns. However, the HS2 Commons Select Committee firmly rejected arguments put forward by Hillingdon Borough Council in favour of replacing the proposed Colne Valley viaduct with a tunnel. See Mr Robert Syms MP, 'High Speed Rail Select Committee: Statement by the Chair' (15 July 2015)

http://www.parliament.uk/business/committees/committees-a-z/commons-select/high-speed-rail-londonwest-midlands-bill-select-committee-commons/news-parliament-20151/150715-statement-on-cv-tunnel/ ( accessed 17 December 2015).

82 Lee has forcefully argued that common law and statute can work in harmony with each complementing the other. The mere fact that a party has had recourse to private nuisance, for example, does not mean that there has been some serious defect in the regulatory process. See Maria Lee, 'The public interest in private nuisance: collectives and communities in tort' (2015) 74(2) CLJ 329 at 354.
} 
must surmount an additional hurdle, namely, the locality doctrine ${ }^{83}$ In short, it must be shown that non-physical loss is out of keeping with the 'character of the neighbourhood.' If the claimant fails to show that the harm was not incompatible with the annoyances and inconveniences that one would expect in a particular locality, the court will rule that there is no actionable nuisance. In this case there would be no need to proceed to an analysis of whether a statutory authority defence may apply. Since the 1980s a tactic employed by defendants has been to argue that a planning decision may bring about rapid changes in the character of the neighbourhood thereby legitimizing hitherto actionable harms.

The starting point is the Court of Appeal decision in Allen v Gulf Oil Refining Ltd, Cumming-Bruce $L$ suggested, obiter, that the effect of authorising the construction of a great enterprise, such as an oil refinery, could bring about an instant change in the character of the neighbourhood. ${ }^{84}$ Thus, the nuisances would only be actionable if they were out of keeping with the normal levels of disruption that one would associate with a refinery. A finding that certain levels of noise or fumes were commensurate with the activity would neutralize nuisance claims and obviate any need to proceed to an analysis of whether the defence of statutory authority could apply. This assertion later gave rise to a line of case law which explored the circumstances in which an individual planning consent could have such an effect. ${ }^{85}$ Although planning consents differ from Acts of Parliament in that they do not give rise to a specific defence, ${ }^{86}$ as planning powers they share the ability to bring about a change in the conditions which prevail on the ground.

This culminated in the Supreme Court decision in Coventry $v$ Lawrence ${ }^{87}$ concerning noise nuisances caused by motorcycle speedway racing. The Supreme Court doubted whether a planning decision could ever bring about a sudden and dramatic change in the character of the neighbourhood. It merely removes a statutory obstacle to pursuing an activity and operates without prejudice to existing common law rights. In reaching this conclusion it seems that Lord Neuberger was greatly influenced by the argument that the planning system should not take away rights without compensation $^{88} \mathrm{His}$ was unimpressed by the argument that the larger the project the more suited a decision to authorise it is to changing the character of the neighbourhood as it 'would be somewhat

\footnotetext{
${ }^{83}$ See St Helens Smelting v Tipping 11 ER 1483, 1486; (1865) 11 HL Cas 642, 650-51 (Lord Westbury).

${ }^{84}$ n 39 above, 172C-D.

85 Gillingham BC v Medway (Chatham Docks) Co Ltd [1993] QB 343; Wheeler v. J.J. Saunders Ltd [1995] 3 WLR 466; Hunter v Canary Wharf [1996] 2 WLR 348, 359F-H (CA) (Pill L); Watson v Croft Promo-Sport Ltd [2009] EWCA Civ 15, [2009] 3 All ER 249.

${ }^{86}$ In Barr v Biffa Waste Services [2012] EWCA Civ 312, [2012] WLR(D) 86 the Court of Appeal emphasised that the defence of statutory authority is confined to specific powers conferred by an Act of Parliament and cannot be extended to administrative measures such as consents and permissions.

87 [2014] UKSC 13, [2014] AC 822.

88 Ibid, at [90] (Lord Neuberger).
} 
paradoxical if the greater the likely disagreeable impact of a change of use permitted by the planning authorities, the harder it would be for a claimant to establish a claim in nuisance. ${ }^{\prime 89}$

Moreover the distinction drawn in Wheeler $v$ Saunders ${ }^{90}$ between strategic planning decisions and ordinary decisions was deemed unworkable. ${ }^{91}$ However, Lord Carnwath accepted that there could be 'exceptional circumstances' in which a planning decision could be regarded as 'the result of a considered policy decision by a competent authority leading to a fundamental change in the pattern of land uses'. In such circumstances it would be unrealistic to consider the character of the neighbourhood in isolation from the issue of planning consent. ${ }^{92}$ Thus, each case would need to be considered in its regulatory context with a view to determining whether the harm was greater 'than a normal person should be expected to put up with. ${ }^{.93}$

The decision of the Supreme Court to rein back the influence of planning decisions, in terms of their effect on the character of the neighbourhood, is to be welcomed. Land use on a small, highly developed island state is an extremely complex issue which entails balancing a myriad of competing considerations. Affording planning decisions pre-eminence in all cases, by enabling them to change the character of the neighbourhood the moment they are published, obstructs this delicate balancing process. Such an approach raises the threshold of actionable harm so as to create the illusion that there never was a legitimate complaint in the first place. ${ }^{94}$ Moreover, it has long been argued that, aside from the influence of planning decisions, the character of the neighbourhood test (or locality doctrine) should not always be allowed to dictate what is reasonable in particular circumstances. In Rushmer v Polsue \& Alfieri Ltd Cozens-Hardy LJ made the memorable assertion that the locality doctrine cannot lead to the automatic conclusion that 'because I live, say, in the manufacturing part of Sheffield I cannot complain if a steam-hammer is introduced next door... ${ }^{95}$ In other words the locality doctrine should not be interpreted as establishing blanket immunity in an entire zone. The common law should be afforded the space to fine-tune the planner's decision by facilitating claims in respect of harms rendered particularly acute by localized circumstances. ${ }^{96}$ Even if one adopted Lord Carnwath's more flexible approach to the effect of planning decisions on the

\footnotetext{
${ }^{89}$ Ibid, at [88] (Lord Neuberger).

${ }^{90}$ Above $\mathrm{n} 85$.

${ }^{91}$ Coventry, above $\mathrm{n} 87$, at [91] (Lord Neuberger).

92 Ibid, at [223] (Lord Carnwath).

93 Ibid, at [183]. For further analysis see Ben Pontin, 'Private Nuisance in the Balance: Coventry v Lawrence (No 1) and (No 2) (2015) 27(1) JEL 119.

${ }^{94}$ It has been argued that decades before the planning system came into being, the locality doctrine facilitated a crude form of zoning which 'trivialized' certain harms by making them relative and thus in-actionable. See Noga Morag-Levine, Chasing the Wind: Regulating Air Pollution in the Common Law State (Princeton: Princeton University Press, 2003) p 56.

95 [1906] 1 Ch 234, 250.

${ }^{96}$ See Peter Cane, Tort Law and Economic Interests (Oxford: Clarendon Press, 1991) pp 90-91 and 410-411.
} 
character of the neighbourhood, it is highly questionable whether long linear projects, such as roads and railways, could be regarded as irrevocably changing the locality along their entire length. A bucolic landscape does not cease to be rural by virtue of the fact that it has a railway running through it. Indeed, the HS2 promoters have expended much effort in persuading objectors that it will be a 'thing of beauty ${ }^{97}$ which will become part of the landscape ${ }^{98}$ rather than destroying it.

Thus, it is unlikely that the promoters and operators of HS2 would simply be able to invoke the locality doctrine in order to neutralize any claims before they got off the ground. Having established a prima facie claim in nuisance it would then be incumbent on the defendants to establish a defence of statutory authority. As we have seen, the success or otherwise of the defence largely rests upon the extent to which the harm can be regarded as inevitable. If the harm is not inevitable it is ultra vires and hence actionable.

However, there is a final important consideration which needs to be addressed. There would be little point in embarking upon the perilous road of litigation if one had an automatic entitlement to compensation under statute or other schemes operated by the promoter. This raises the issue of the adequacy of compensation. Clearly, if statutory compensation, or other monies payable as part of a compensation package for the scheme, proves to be inadequate, the common law may have a vital role to play in terms of providing an alternative source of compensation.

\section{THE ADEQUACY OF STATUTORY AND DISCRETIONARY COMPENSATION}

Much of the debate and controversy surrounding HS2 has focused on the adequacy of the compensation package. There is a statutory minimum entitlement to compensation in respect 'injurious affection' arising from the construction and operation of roads, railways and other infrastructure projects, where damages cannot be recovered at common law due to the statutory

\footnotetext{
${ }^{97}$ An assertion made by the then Secretary of State for Transport, Justine Greening, in 2012: see James Kirkup, 'HS2 will go ahead - and it will be a thing of beauty, says Justine Greening' The Telegraph (London, 22 June 2012) http://www.telegraph.co.uk/news/uknews/road-and-rail-transport/9347795/HS2-will-go-ahead-and-itwill-be-a-thing-of-beauty-says-Justine-Greening.html (accessed 19 December 2016).

${ }^{98}$ HS2 Ltd asserts that 'The landscape design will seek to enhance the features and qualities that give the landscape its particular value.' See HS2 Ltd, 'Landscape Design Approach (July 2016) https://www.gov.uk/government/uploads/system/uploads/attachment_data/file/550791/HS2_Landscape_De sign_Approach_July_2016.pdf (accessed 19 December 2016).
} 
authority defence.${ }^{99}$ However, political considerations have compelled the Government to provide a discretionary compensation package which goes beyond the minimum requirements of existing laws on compulsory purchase. ${ }^{100}$ At the epicentre of the development is the 'surface safeguarded area' which includes the land needed to build the line and property up to 60 metres away from the route. All owner-occupiers living within this zone are entitled to participate in the 'express purchase scheme' whether or not their home or business actually has to be demolished to make way for the line. This entitles claimants to receive the full un-blighted market value of the property plus $10 \%$ (capped at $£ 49,000$ ) to reflect the undesired nature of the sale. Where property within this zone will be left intact and habitable and the owner-occupier is intent on remaining there he may participate in the alternative 'rent back' scheme. In short, the Government will buy the property for its full unblighted market value and let it back to the former owner-occupier under a Crown tenancy. In this way the former owner may continue to live at the property without having to absorb the massive reduction in capital value.

The compensation scheme is then pushed outwards to reflect the impact on those living in the vicinity of the line. Those living up to 120 metres of the line in rural areas (the 'rural support zone') ${ }^{101}$ will be able to sell their homes to the Government if they wish ('voluntary purchase') at full unblighted market value until one year after the line opens. Persons falling with the rural support zone are also afforded the alternative option of accepting a 'cash offer' amounting to $10 \%$ of the unblighted market value of the property (with a minimum payment of $£ 30,000$ and a cap of $£ 100,000$ ). Persons falling within this category are also eligible to participate in the 'rent-back' scheme. Beyond 120 metres the 'homeowner payment scheme' comes into operation which offers three bands of payments for those living up to 300 metres from the line. ${ }^{102}$ The payments are confined to owner occupiers and it is notable that the guidance avoids the use of the term compensation. Instead, it is declared that the 'aim is to ensure that people who live near the line of route receive an early share

\footnotetext{
${ }^{99}$ See section 10 Compensation Act 1965 and Part 1 Land Compensation Act 1973. Where harm is not inevitable it would not be covered by the statutory authority defence and would thus be irrecoverable under the legislation. In this case it would be necessary to maintain an action at common law.

${ }^{100}$ As regards the special compensation schemes for HS2, all guidance documents can be accessed via the following Government website: https://www.gov.uk/claim-compensation-if-affected-by-hs2 (accessed 17 December 2015). For a concise overview relating to phase 1 see, HS2 Ltd, 'Guide to HS2 Property Schemes: London-West Midlands (Phase 1)' (January 2015) https://www.gov.uk/government/publications/hs2-propertyschemes-between-london-and-the-west-midlands (accessed 17 December 2015).

${ }^{101}$ It should be noted that the rural support zone is interpreted very broadly and encompasses leafy suburbs in addition to open country. The HS2 property scheme map showing the Northolt tunnel portal is particularly informative in this respect. After leaving Euston the line passes through a tunnel under central and a large part of Greater London. The compensation scheme bands appear as a multi-coloured ribbon flowing from the tunnel portal as the line emerges into the leafy, but far from bucolic, suburbs of Ickenham. See HS2, 'Property Schemes for the London - West Midlands HS2 route: Map books vol 1 - Greater London Boroughs' (January 2015), map PC-01-013.

102 The bands of payments are as follows; $120-180 \mathrm{~m}$ : $£ 22,500 ; 180-240$ : $£ 15,000 ; 240-300 m: £ 7,500$.
} 
in the benefits of HS2.' In other words, it is promoted as a windfall rather than compensation for a loss.

Finally, the 'need to sell' scheme ${ }^{103}$ enables persons, who may not qualify to have their properties bought by the Government under any of the above schemes, to sell their properties to the Government at un-blighted market value provided that there are compelling reasons for needing to move. ${ }^{104}$ For example, properties situated a considerable distance from the line, and far outside the outer limits of the rural support zone, may be blighted if they fall on a HS2 construction traffic route. A person with respiratory problems could argue that he needs to move because of the impact of additional traffic fumes on his health. Alternative compelling reasons could include the need to move in order to take up a new job. ${ }^{105}$

The HS2compensation package offered by the government, which does not form part of the Bill itself, is comprehensive and goes beyond the statutory minimum. The ongoing impact of the line on the quality of life of those living closest to it is reflected in the terms upon which such persons may sell their property to the Government. It is possible that a modern equivalent of Mrs Brand, living so close to HS2 that she is affected by vibration, ${ }^{106}$ would qualify for compensation both under the terms of the scheme and the statutory minimum entitlement to compensation under the Land Compensation Act 1973. However, it is clear that there may still be individuals who fall outside any of the compensation packages who are nevertheless affected by the construction or operation of the line. As noted above, if the harm is not inevitable and is thus unlawful, compensation would not be payable under existing land compensation legislation either. A cursory inspection of the HS2 property maps shows the arbitrary nature of the boundaries which divide near neighbouring properties and run through the middle of properties in some cases. Those falling marginally outside a boundary are likely to be equally affected as those falling just within it. Moreover, those who participate in any of the schemes may find that the financial offer which they accepted fails to properly compensate for ongoing nuisances. For example, a person living within 120 metres of the line in a rural support zone, who accepts a cash offer and elects to stay, may subsequently regret his

\footnotetext{
${ }^{103}$ This was formally known as 'the exceptional hardship scheme' and this description still applies to phase 2 of the line.

${ }^{104}$ Other restrictions on the availability of the scheme include the need to show that the claimant was unaware of the project at the time he bought the property. Anyone who bought their property after the initial preferred route was announced on 11 March 2010 is deemed to have known about the project. Efforts must also have been made to sell the property with no offers received within $15 \%$ of the 'realistic un-blighted value of the property.'

${ }^{105}$ The 'rent back' scheme applies as an alternative in all cases where the Government has agreed to buy the property which means that it could also be used in the context of 'need to sell'. However, given that this scheme is aimed at those who need to move it is difficult to envisage which claimants would wish to remain having sold the property.

${ }^{106}$ See Hammersmith \& City Rly v Brand, above n 25.
} 
decision if the magnitude of the nuisances is greater than he anticipated. As regards persons who live further out, as noted above, payments made under the 'homeowner payment scheme' are not intended to be compensatory in any case. Although it is not readily apparent from the published documentation, HS2 Ltd has confirmed that such payments are without prejudice to existing common law rights. ${ }^{107}$ Thus, an individual who elects to remain in his house but finds that the compensation awarded is inadequate in the light of the magnitude of the harm once the line is put into operation would not be precluded from pursuing an action in nuisance.

It is worth noting that the fact that an individual could pursue an action in nuisance, notwithstanding any entitlement to compensation under the HS2 schemes, means that he would not be confined seeking a financial settlement. It is conceivable that he could seek injunctive relief in order, for example, to compel the operator to install additional screening measures at a sensitive location such as a riding school. ${ }^{108}$ As we have seen, the select committee process, undertaken as part of the hybrid Bill procedure, has resulted in the adoption of higher fencing or other measures at specific locations. However, the full impact of the line will not be apparent until it is put into operation. It may transpire that there is a need for additional abatement measures at other locations. If the operator declines to act, and there is no regulatory enforcement action, ${ }^{109}$ an injunction may provide the only means of securing the adoption of such measures.

This may raise fears that the costs of the project could be escalated in an unsustainable manner and that claimants may seek to impose unrealistic solutions on the operator. However, there are two control mechanisms which should allay such fears. Firstly, the terms of an injunction must reflect what is technically feasible and financially viable. ${ }^{110}$ Secondly, following the decision of the Supreme Court in Coventry $v$ Lawrence, ${ }^{111}$ it seems that the courts will have greater discretion to award damages in lieu of an injunction. ${ }^{112}$ This is because the Court advocated some relaxation of the

\footnotetext{
107 This point was clarified by way of a freedom of information request: emails from HS2 Ltd to author (1 and 20 July 2015).

${ }^{108}$ See example pertaining to the Chiltern Railways Evergreen 3 project, abovet $\mathrm{n} 79$.

${ }^{109}$ Noise caused by HS2 could conceivably constitute a statutory nuisance under Part III of the Environmental Protection Act 1990. However, sch 26 paras 2-3 of the HS2 Bill establishes a defence to any such action if the harm could not have been reasonably avoided. It is arguable that this is a less onerous standard from the defendant's perspective that the 'inevitability of harm' criterion embodied by the statutory authority defence in private nuisance.

${ }^{110}$ See Jordan v Norfolk CC [1994] 1 WLR 1353.

${ }^{111}$ Coventry, above $\mathrm{n} 87$,.

112 The discretion was first introduced by Lord Cairn's Act (The Chancery Amendment Act 1858) and currently resides in section 50 of the Senior Courts Act 1981. For academic arguments in favour of loosening the criteria see Mark Wilde, 'Nuisance law and damages in lieu of an injunction: challenging the orthodoxy of the Shelfer criteria' in SGA Pitel, J.W. Neyers and E. Chamberlain (eds), Tort law: challenging orthodoxy (Oxford: Hart, 2013).
} 
restrictive 'Shelfer criteria'113 which have hitherto governed the discretion. Moreover, it was stated that public interest considerations, such as the economic benefits of an activity, should be taken into account. ${ }^{114}$ Thus, if no viable or cost effective technical solution falls readily to hand it is most unlikely that the Court would simply grant an injunction leading to the complete cessation of operations. Rather, damages would be awarded in full and final settlement of the claim. In this respect the common law would have a role to play in terms of securing damages for those who may not have been included in the statutory and discretionary compensation packages.

This additional discretion should allay fears that injunctions would be sought with a view to imposing unduly costly or unworkable solutions on the operator. Moreover, an interpretation of the inevitability of harm criterion, which encompasses technical feasibility and cost, ${ }^{115}$ would enable the statutory authority defence to filter out claims for 'gold plated' solutions before the issue of injunctive relief arose. Thus, to use the example of Wendover and the amendments made by the House of Commons HS2 Select Committee, ${ }^{116}$ it is one thing to extend a green tunnel whilst matters are still at the planning stage, it would be quite another to extend a green tunnel after the line is built. In this case it is far more likely that a court, in response to a nuisance claim, would stipulate more or higher fencing to alleviate noise nuisance.

Having acknowledged the utility of a pragmatic approach, it is worth noting that, in order to make effective use of the common law in this context, a degree of boldness on the part of the courts may be called for. The consequences of a lack of boldness are illustrated by the railway sparks issue which are alluded to at various points in this article. When the first railways were authorised by way of the private Bill procedure in the nineteenth century, it cannot have been Parliament's intention that huge tracts of farmland, numerous buildings and other property would be laid waste by fires caused by locomotive sparks. Yet, as previously noted, the railway industry successfully argued until the demise of steam traction in the 1960s that such losses were the unavoidable consequence of utilising the powers conferred by section 86 of the Railway Clauses (Consolidation) Act 1845. Litigants frequently argued that such losses could have been prevented through fitting spark arrestors but the courts proved susceptible to technical arguments relating to the adverse effect of such devices on engine performance. A far bolder approach is exemplified by the case of Manchester Corporation v Farnworth. ${ }^{117}$ Above it was noted that the House of Lords held that the inevitability of

\footnotetext{
${ }^{113}$ Shelfer above $\mathrm{n}$ 30. See AL Smith $\mathrm{L}$ at 322-23.

${ }^{114}$ Coventry, above $\mathrm{n} 87$. See, for example, Lord Neuberger at [124].

${ }^{115}$ As noted above this was the formulation favoured by Lord Dunedin in Manchester Corporation $v$ Farnworth, above $\mathrm{n} 32$.

${ }^{116}$ Above $\mathrm{n} 64$.

${ }^{117}$ Farnworth (HL), above $\mathrm{n} 32$.
} 
harm criterion incorporated considerations of technical feasibility and cost. Nevertheless, as regards the possibility of reducing the emissions from the power station, their Lordships approached the technical evidence adduced by the defendants with a healthy degree of circumspection. It will be recalled that, despite the fact that a clear technical solution did not fall readily to hand, an injunction was granted and then suspended on the understanding that the defendants would use their best endeavours to find a solution. ${ }^{118}$

\section{CONCLUSION}

As Lord Denning MR pointed out in Allen v Gulf Oil Refining $L t d,{ }^{119}$ the Railway Revolution could not have happened in the absence of statutory authority. Without it the development of the railways would have been hamstrung by strict liability for unavoidable harm. After a gap of a century this nation has again started building major railways, albeit at a less frenzied pace, commencing with the Channel Tunnel Rail Link (CTRL or HS1) and continuing with Crossrail and now HS2. It is difficult to resist drawing comparisons between these late twentieth and early twenty first century megaprojects and their Victorian counterparts. Many of these links are superficial or purely symbolic; such as the decision to resurrect Curzon Street, the original terminus of Robert Stephenson's London to Birmingham Railway, as the Birmingham terminus of the HS2 spur. ${ }^{120}$ However, other aspects of nineteenth century railway heritage are deeply embedded in the DNA of HS2 as demonstrated by the extent to which the annexes of the HS2 Bill are replete with references to musty items of Victorian Railway Legislation. Not least of these is the inclusion of section 86 of the Railway Clauses (Consolidation) Act 1845 which forms the basis of statutory authority in terms of nuisances caused by the running of trains.

Nevertheless, the need to show that the harm was inevitable means that statutory authority does not preclude the common law from playing a vital role in terms of dealing with some of the less desirable externalities which may flow from HS2; such as nuisances caused by noise and vibration. Indeed, it is vital that the common law does in fact play a role in this respect in that, despite the complexities and thoroughness of modern planning processes such as environmental assessment, it is simply not possible to foresee all possible harms and design them out of the scheme. Moreover,

\footnotetext{
${ }^{118}$ As Pontin has argued, granting but then suspending injunctions has sometimes been used as a means of allowing the defendant to continue his activities whilst exerting pressure to find a solution - this may often take years. See Ben Pontin, Nuisance Law and Environmental Protection: A study of nuisance injunctions in practice, above $\mathrm{n} 54$.

${ }^{119}$ Allen (CA), above $\mathrm{n} 39$ at $165 \mathrm{C}$.

${ }^{120}$ See HS2 Ltd, 'High Speed 2 Information Paper: H1: Birmingham Curzon Street Station' (12 April 2015) https://www.gov.uk/government/uploads/system/uploads/attachment_data/file/517740/H01__Curzon_Street_Station_v1.3.pdf (accessed 21 December 2016).
} 
where harms are foreseen, but it is deemed impossible to find cost effective engineering solutions, there may be many injured parties who do not qualify for compensation under the terms of existing legislation or the special scheme established by HS2 Ltd under the auspices of the Government. As such, common law has the potential to fulfil a vital role in terms of 'fine tuning' compensation by remediating such losses. This could be effected through damages, or, in rare cases, injunctive relief (subject to the more flexible approach to damages in lieu of an injunction heralded by Coventry $v$ Lawrence). ${ }^{121}$

This would enable the common law to play a crucial role in securing further mitigation measures along the route of HS2 or at least compensation where such measures are deemed infeasible. However, in order to fulfil this role effectively, the courts must approach claims that certain harms are simply unavoidable with a degree of wariness. For example, noise and vibration have featured heavily in the debates surrounding the passage of the HS2 Bill. This is hardly a new problem and in the Brand ${ }^{122}$ case the courts did not question the fact that uncomfortable levels of noise and vibration were inevitable. Technology is now lightyears ahead of where it was in the 1860s and there is far more scope for mitigating such harms. During the passage of the HS2 Bill petitioners have called for better screening measures, in the form of landscaping or fencing, at sensitive locations. As noted above, this resulted in the House of Commons Select Committee requiring additional noise protection at Wendover. Moreover, the technology exists to reduce vibration and some experts have advocated greater use of 'slab track.' Taking all this into account a contemporary court should be far more willing to challenge expert evidence than its Victorian predecessors.

This would help to ensure that a greater proportion of the costs associated with HS2 are mitigated or internalised by way of damages. As Bramwell B put it in Bamford $v$ Turnley, when alluding to the railway sparks cases, 'It is for the public benefit that trains should be run, but not unless they pay their expenses. ${ }^{\prime 23}$ In this respect the common law may have a vital role to play in ensuring that HS2 fully pays its way. This is not something that can be guaranteed by the Government compensation package alone.

\footnotetext{
${ }^{121}$ Above $\mathrm{n} 87$.

122 Above $n 22$.

${ }^{123}$ (1862) 3 B \& S 66, 85; 122 ER 27, 33.
} 